\title{
THE INFLUENCE OF THE QUALITY OF CORPORATE GOVERNANCE ON THE EFFICIENCY OF GERMAN COMPANIES: LEGAL EDUCATION OF THE ISSUE
}

\author{
Haytham Shakarna \\ Ph. student (Mr.) Department of civil law and procedure and international private law \\ 6 Miklukho-Maklaya Street, Moscow, 117198, Russian Federation, \\ h.shakarna@yahoo.com
}

\begin{abstract}
Currently, international experience shows that corporate governance plays an essential role in developing an organization and improving its performance. International integration helps attract practical and modern corporate governance standards from other countries. The study's relevance lies in the study of factors affecting the efficiency and corporate governance of German companies. The article analyzes and evaluates the importance and quality of corporate governance for emerging companies and displays the issues on the learning process at university levels. The importance is determined by the high level of business and agency risks. The German corporate governance model is typical for Central Europe and Scandinavian countries but is less typical for Belgium and France. It is characterized by a system of relationships between shareholders and the company's management, mechanisms that allow shareholders to control the company's work and its management activities. There are several corporate models: Anglo-American (outsider), German (insider), Japanese, and family. The international integration demands for deeper understanding the problems while learning and teaching law.
\end{abstract}

The study aims to examine the tools in the corporate governance code in German companies. There are several types of indicators. The cost concept is aimed at improving the company's efficiency from the point of view of the corporation shareholders. Generally, the legal education should include not only the theoretical insight of the issue, but also give practical advice to future graduates aiming at working in international companies.

The novelty of the research rests in the development of theoretical and methodological provisions and substantiation of a conceptual approach to the relationship between the quality of corporate governance, the economic interests of the subjects of the corporation, and its life cycle on the example of German companies.

Research objectives are to study theoretical approaches to assessing the quality of corporate governance in German companies; determine the conditions and factors for the formation of economic interests; bring the study of international law at universities to the standard level according to the European framework of education.

The article concludes that effective corporate governance today plays a much more crucial role than just another legal superstructure. The outcomes of the article could be of importance in shifting the process of learning and teaching in the Russian universities if they are eager to move ahead "armed" with necessary knowledge in the rapidly changing market of education.

Keywords: legal education; corporate governance; efficiency; corporate rating; university education; corporation; balanced scorecard; value-oriented management. 


\section{INTRODUCTION}

The international market is the main field for economic activity and expansion of large Russian companies. It enables effective integration and is the foundation for building trust. It is important for foreign companies and individuals to have full access to all information about the organization with which they cooperate. One need to know who the partner is, what goals it sets for the co6o, what the organization is based on, what is the organizational structure, how it acted in its country and what its plans are for international development, the openness of companies and the reliability of the information provided.

The general international standards should be fully consistent with the current corporate governance (CG) practice. Business pragmatism pushes it to take certain steps to improve the level of corporate governance [1] - the organizational structure will protect shareholders and investors from financial risks, their interests and form full compliance with the company's responsibility to them. Rating is the most comprehensive quality assessment [2], capable of reflecting all the advantages and disadvantages of the company in front of stakeholders. This tool is aimed at measuring the actual performance of activities, and not at compliance with all the formal rules enshrined in documents.

Corporate governance emerged as an objective necessity for large business, which was preceded by a long evolutionary process. At a certain stage, the international community was forced to develop uniform norms and standards to simplify and unify the processes of managing corporate structures, regardless of their location. Optimization is meeting the interests of each stakeholder group, exercise and protection of rights, as well as the resolution of intergroup conflicts of interest.

The application of corporate governance codes has received considerable attention both in research carried out at the request of the Commission of the European Union and in research carried out in Europe and in the world.

The corporate governance system helps the company to most effectively organize the relationship between its owners, management and other stakeholders on the ownership and management of the company, as well as the distribution of its profits. The initial goal of building, improving and developing any system is to reduce the risks associated with the agency problem when separating property from management.

The relationship between corporate law and the legal environment has changed in recent times under the impact of the financial crisis, while a number of issues have been moved from a self-regulatory code to a legally binding provision. In particular, the reluctance to improve, adopt and effectively implement voluntarily the provisions of the code in remuneration has prompted legislative measures in some states. This issue clearly reflects the often-mentioned tension between codes and legislation, and the fear that over time legislation will absorb a significant part of the content of the codes, which is one of the determining factors for improving the content of the codes. It is necessary to understand the meaning of the corporate governance code depending on the applicable legal structure within which they are to operate.

Laws are becoming more and more diverse, so the role of codes, which is an additional source of rules of conduct, varies significantly. Monitoring measures vary considerably, but not necessarily proportionally. Embedding codes in the legal framework raises questions: does the legislation take into account the existing provisions of the code, and whether remedies can be applied in case of violation of the provisions of the code?

\subsection{German Management System}

The German management model is very similar to the Japanese one, therefore it is sometimes called the Japanese-German one. However, there are still certain differences between them. The founder of the German model is considered to be a sociologist, scientist and economist who lived at the beginning of the 20th century, Marx Weber. Soon it spread to Germany, Austria, Switzerland and other Western countries, and remains relevant until now.

Typically, the German management model is used in two cases:

1. Low degree of stock market development.

2. Concentration of equity capital in the hands of various institutional investors, a small share in private investors [3].

The German management model is characterized by the following features:

1. Consent between employees and management. 
2. Long-term cooperation.

3. Financial systems in which the bank is the key link.

4. Dominance of outsiders.

5. Focus on other stakeholders.

6. Encouraging of vocational training.

\subsubsection{Features of the German model of corporate governance}

Professional training (and its quality) is extremely important in Germany. Particular attention is paid to technical and engineering training, which is considered one of the best in Europe. The education system provides the necessary training for young people between the ages of 16 and 21 .

Vocational education is held by $70 \%$ of workers in various companies in Germany who have received training and qualifications. For comparison, only $40 \%$ of workers in the Netherlands and $30 \%$ in England and the United States have such qualifications.

In contrast to the USA and Great Britain, Germany has implemented a three-tier model of managing jointstock companies: a general meeting of shareholders, a supervisory board and a management board. Sometimes in research papers, especially in English, the supervisory board and the board are considered together as a bicameral board of directors (Fig. 1). However, one cannot agree with this, since German law provides precisely for two separate bodies of a joint-stock company with different functions and formation procedure.

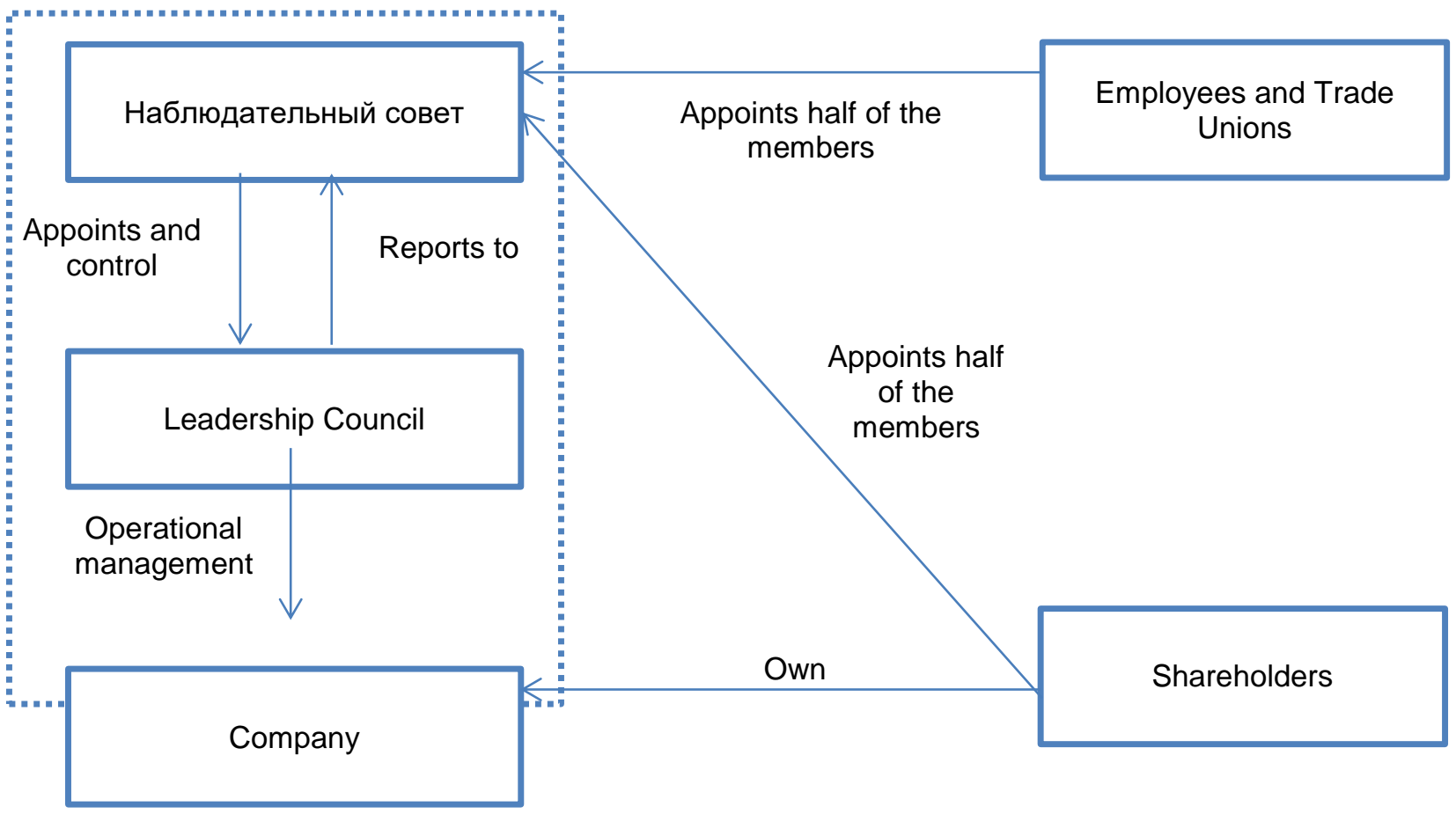

Fig. 1. German model of corporate governance [7]

Equity capital in countries with the German corporate governance model is highly concentrated. In large German companies, the five largest shareholders hold more than $40 \%$ of the shares of each of these companies. This is more than double the concentration of ownership of British firms and $60 \%$ higher than in North America. In Germany, and this is its characteristic feature, in more than $71 \%$ of joint-stock companies the owner controls over $50 \%$ of the shares, and in $35 \%$ of joint-stock companies all $100 \%$ of the shares belong to one owner [4, p. 4] (Fig. 2). Individual investors - individuals in Germany, account for $17 \%$ of the shares, while corporate investors control $64 \%$ of the shares of German companies (22\% are financial institutions, including banks, insurance companies, pension funds, etc.; $42 \%$ are non-financial corporations). In addition, in the capital structure of corporations in Germany there is a large share of foreign investors $(14 \%)$ and the state $(5 \%)$, which is more than twice as high as similar indicators, for example, in Great Britain 
[5].

A specific feature of the German corporate governance system, enshrined in legislation, is the participation of employees in the management of the company. According to the German law adopted in 1976, in companies with more than 500 employees, the latter elect their representatives to the supervisory board (Board of Directors). In companies with more than two thousand employees, half of all seats on the supervisory board are given to elected representatives, the other part is elected by shareholders. The number of members of the supervisory board varies depending on corporations from 9 to 22 people. Thus, through this body, the basic principle of social interaction is implemented.

The large proportion of non-financial corporate investors indicates the prevalence of cross-shareholding in Germany, meaning that German companies are in many cases shareholders of each other. It allows companies to closely interact with each other, forming "informal" holdings, which, due to the closed nature of information on the composition of shareholders, are not very noticeable to outside observers. It is interesting that the German "system of participation", which allows the owner of not too large capital to dominate gigantic areas of production, was described by V.I. Lenin in Imperialism as the Highest Stage of Capitalism (1916). Since then, this system has not undergone significant changes.

The largest shareholders in Germany are Deutsche Bank AG, Dresdner Bank AG, Komerzbank AG, as well as various insurance companies and investment funds. For example, Deutsche Bank AG controls such industrial concerns as Bosch, Siemens. Hocht, Grundig, Krupp are grouped around Dresdner Bank AG. The parent holdings own, on average, shares and control the activities of 150 companies.

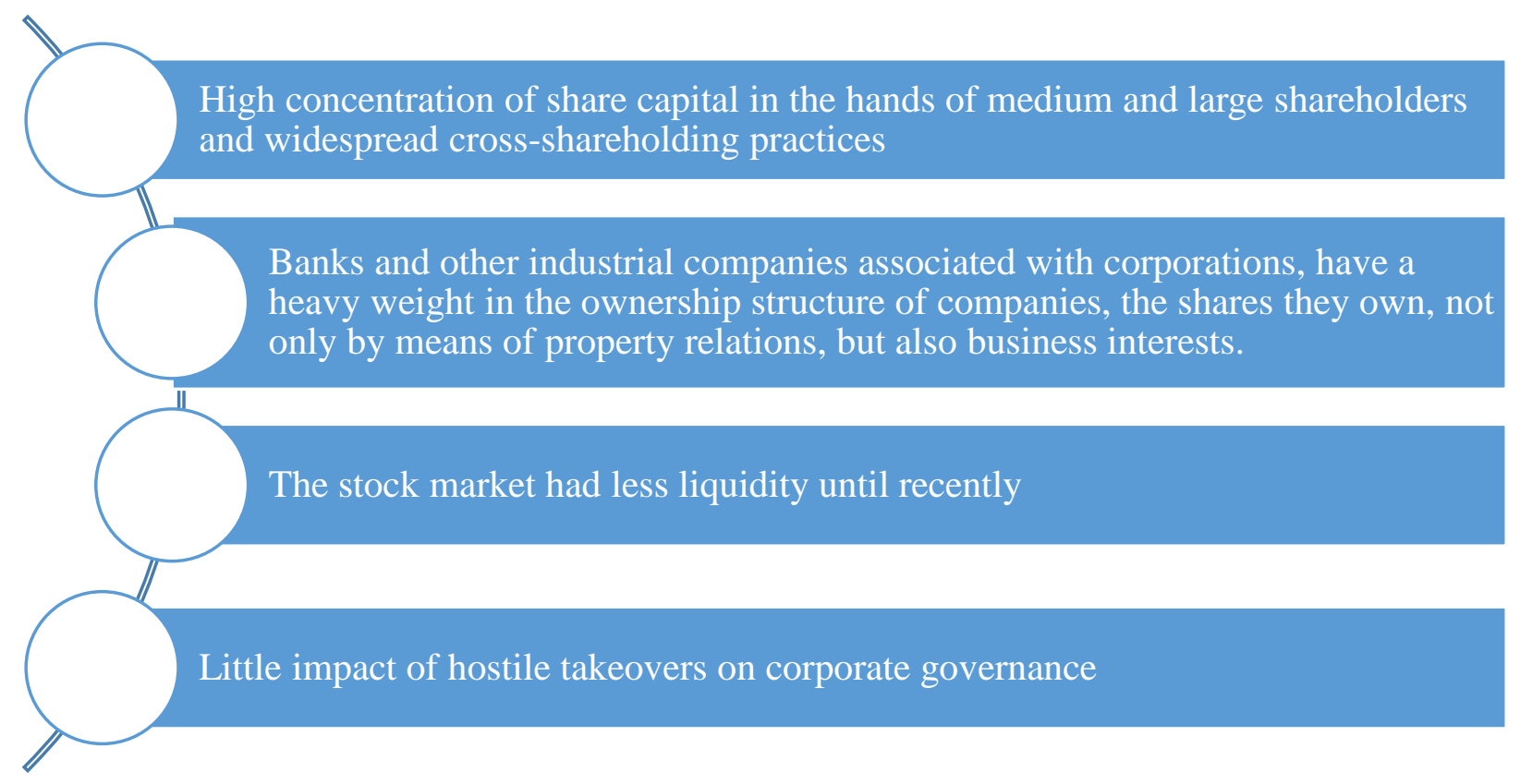

Fig. 2. Features of the formation of the German model of corporate governance

The German model received its active distribution in the Central European and Scandinavian countries (Fig. 3)
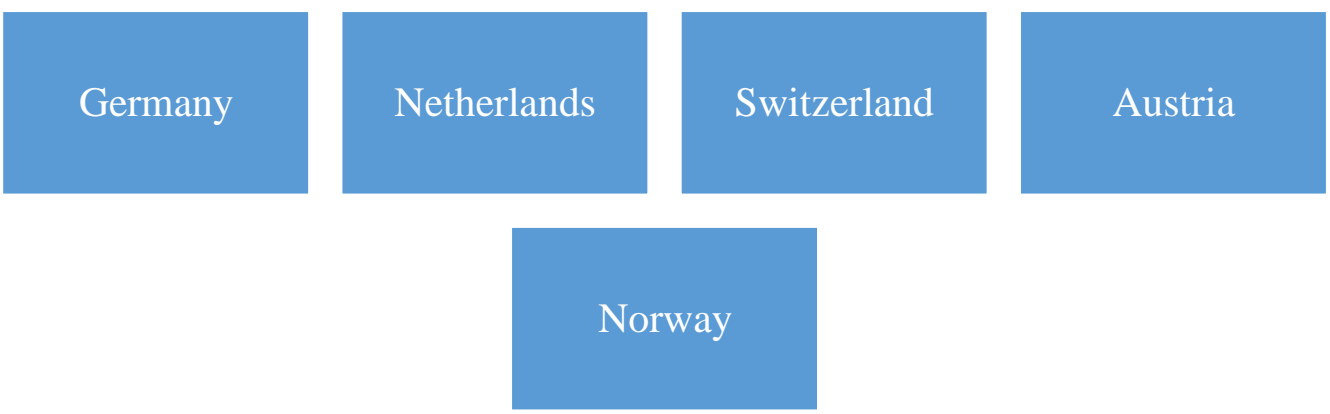

Fig. 3. Geography of distribution of the insider model of corporate governance 


\section{COMPANY PERFORMANCE INDICATORS}

Currently, there are two main types of indicators that assess the effectiveness of a company:

- Operating indicators;

- Cost indicators.

If we consider operating indicators, then to measure them, first of all, a number of financial profitability ratios are used: equity, assets, sales.

Leaders of leading companies now place more emphasis on short-term goals than on strategically important tasks, which leads to a decrease in overall strategic effectiveness. In addition, all decisions made by the company's board have a time lag, since many of them cannot be implemented in the shortest possible time, because a real assessment of the effectiveness of these decisions can only be given based on future prospects. Thus, it is rather difficult to relate the corporate governance rating to the company's operating activities. In this regard, it is more expedient to give precisely the cost estimate of a particular decision, on its basis to determine the corporate governance rating [6].

\section{CONCLUSION}

The main task of corporate governance is to fully take into account the requirements of all stakeholders involved in the life of a public company. Generally speaking, these are management, shareholders, employees, regulators, society, etc. However, in practice, corporate governance focuses mainly on the problem of the relationship between the firm's management and investors. Moreover, all modern codes of corporate governance are aimed at protecting the interests of shareholders, since from the very beginning it is believed that the company's management is much closer to its property, assets and financial statements, and, therefore, can abuse its positions to the detriment of investors.

Thus, today corporate governance and its basic principles, enshrined in a number of codes, are aimed at protecting investors through deep and wide control over the reporting and assets of a public company.

Everyone is interested in ensuring the interests of each other and is focused on results. For this reason, incentive measures are provided. The inclusion of some employees in the supervisory board of the company is considered as motivation.

Thus, the continental model of corporate governance, which has been developed in European countries, provides for a clear structure of the enterprise, which allows ensuring the interests of its participants and achieving the set goals.

\section{ACKNOWLEDGEMENT}

This paper has been supported by the RUDN University Strategic Academic Leadership Program.

\section{REFERENCE LIST}

1. Bagina, K.C. (2018) Development of innovative management mechanisms by a modern Russian company. No. 2. pp. 13-17.

2. Dementyeva, A.G. (2019) Ratings of corporate management guidelines for making investment decisions // Facets of Economics. No. 3. pp. 19.

3. https://hr-portal.ru/article/nemeckaya-model-korporativnogo-upravleniya-glavnye-priznaki-ipreimushchestva

4. Lukashin, A.V. (2017) Comparative corporate finance and corporate governance // Corporate finance management. No. 3.

5. Kondratyev, V. (2018) Corporate governance: features and development trends // Problems of theory and practice of management. No. 1.

6. Kpacovskiy, Yu.D. (2019) Socio-cultural foundations of business organization management: scientific position / Yu.D. Kpacovsky. Moscow, Unity-Dana, 394 p.

7. https://blog.iteam.ru/korporativnoe-upravlenie-modeli-sistema-upravlenie-riskami/\#i-13 